\title{
Effects of stage of lactation and dietary concentrate level on energy utilization by Alpine dairy goats
}

\author{
I. Tovar-Luna, ${ }^{*} \dagger$ R. Puchala, ${ }^{*}$ T. Sahlu, ${ }^{*}$ H. C. Freetly, $\ddagger$ and A. L. Goetsch ${ }^{* 1}$ \\ *American Institute for Goat Research, Langston University, Langston, OK 73050 \\ †Universidad Autónoma Chapingo, Unidad Regional Universitaria de Zonas Aridas, Bermejillo, 35230 Durango, México \\ fUSDA, ARS, US Meat Animal Research Center, Clay Center, NE 68933
}

\section{ABSTRACT}

Twenty-four lactating and 13 nonlactating Alpine goats were used to determine effects of stage of lactation and dietary concentrate level on energy utilization. Diets comprising 60 or $20 \%$ concentrate $(60 \% \mathrm{C}$ and $20 \% \mathrm{C}$, respectively) were consumed ad libitum by lactating animals and at a level of intake near maintenance by nonlactating animals. Measurement periods were d 25 to 31 (early), 87 to 94 (mid), and 176 to 183 (late) of lactation. Eleven observations were made in early and mid lactation for each diet, and 8 and 7 were made in late lactation for the $60 \% \mathrm{C}$ and $20 \% \mathrm{C}$ diets, respectively. Efficiency of metabolizable energy (ME) use for maintenance $(66.9,71.4$, and $61.1 \%$ for early, mid, and late lactation, respectively) and the maintenance ME requirement $(479,449$, and $521 \mathrm{~kJ} / \mathrm{kg}$ of $\mathrm{BW}^{0.75}$ for early, mid, and late lactation, respectively) determined with nonlactating animals differed among stages of lactation. The efficiency of ME use for maintenance was similar between diets, but the maintenance requirement tended to be greater for the $60 \% \mathrm{C}$ than for the $20 \% \mathrm{C}$ diet $\left(504\right.$ vs. $463 \mathrm{~kJ} / \mathrm{kg}$ of $\mathrm{BW}^{0.75}$ ). The latter difference may have involved greater ME intake for the $60 \% \mathrm{C}$ diet, resulting in a slightly greater difference between $\mathrm{ME}$ intake and total heat energy for the $60 \% \mathrm{C}$ compared with the $20 \% \mathrm{C}$ diet $(11$ vs. $-8 \mathrm{~kJ} / \mathrm{kg}$ of $\left.\mathrm{BW}^{0.75}\right)$. Intake of $\mathrm{ME}$ by lactating goats was greater for the $60 \% \mathrm{C}$ than for the $20 \% \mathrm{C}$ diet (18.6 vs. 16.3 $\mathrm{MJ} / \mathrm{d}$ ). Recovered energy in lactation from mobilized tissue tended to be greater for the $60 \% \mathrm{C}$ than for the $20 \% \mathrm{C} \operatorname{diet}(8.44$ vs. $6.55 \mathrm{MJ} / \mathrm{d}$ ) and differed among stages of lactation $(2.60,1.59$, and $1.13 \mathrm{MJ} / \mathrm{d}$ in early, mid, and late lactation, respectively). Recovered energy in tissue gain was similar among stages of lactation and between diets and was not different from 0. Efficiency of use of dietary ME for lactation differed among stages of lactation (59.5, 51.9, and $65.4 \%$ for early, mid, and late lactation, respectively) and tended to be greater

Received April 5, 2010.

Accepted June 21, 2010.

${ }^{1}$ Corresponding author: goetsch@luresext.edu for the $60 \% \mathrm{C}$ than for the $20 \% \mathrm{C}$ diet (64.2 vs. $54.9 \%$ ). The efficiency of use of dietary ME for maintenance and lactation was similar among stages of lactation and was greater for the $60 \% \mathrm{C}$ compared with the $20 \% \mathrm{C}$ diet (64.3 vs. $60.9 \%)$. Predicted milk yield from National Research Council requirements was reasonably accurate. In conclusion, using data of nonlactating goats to study energy utilization for maintenance in lactation has limitations. Efficiency of energy use by lactating dairy goats consuming diets high in concentrate appears greater than that by goats consuming diets low in concentrate. Despite differences in nutrient requirement expressions, observations of this study support National Research Council recommendations of energy requirements of lactating dairy goats.

Key words: dairy goat, lactation, energy

\section{INTRODUCTION}

Energy requirements of lactating dairy goats recommended by NRC (2007) are based on the study of Nsahlai et al. (2004) involving a database of treatment means from the literature. These observations were of goats with intake at or near the ad libitum level. Although for dairy cattle one efficiency of energy utilization is assumed for the sum of the maintenance need and that for milk production (NRC, 2001), Nsahlai et al. (2004) employed an efficiency of dietary ME used for maintenance based on an equation of AFRC (1998) accounting for diet metabolizability. Also, a constant efficiency of utilization of mobilized tissue energy for lactation (AFRC, 1993, 1998) was assumed to derive one efficiency with which dietary ME is used for lactation. Information available for observations in the database employed by Nsahlai et al. (2004) was not conducive to thorough consideration of potential effect of factors such as dietary concentrate level or stage of lactation.

Dietary forage level affects several conditions that influence efficiency of energy metabolism (NRC, 2007). For example, Ngwa et al. (2009) indicated that based on tissue mass, energy expended by the metabolically active gastrointestinal tract was greater for a diet with 
Table 1. Composition of $\operatorname{diets}^{1}$ consumed by lactating Alpine goats (\% of DM)

\begin{tabular}{|c|c|c|}
\hline \multirow[b]{2}{*}{ Item } & \multicolumn{2}{|c|}{ Diet } \\
\hline & 20 & 60 \\
\hline \multicolumn{3}{|l|}{ Ingredient } \\
\hline Cottonseed hulls & 20.21 & 20.42 \\
\hline Ground alfalfa hay & 60.00 & 20.19 \\
\hline Ground corn & 7.00 & 32.85 \\
\hline Soybean meal & 3.00 & 11.31 \\
\hline Blood meal & 0.39 & 1.04 \\
\hline Fish meal & 0.77 & 3.57 \\
\hline Molasses & 2.50 & 2.52 \\
\hline Fat $^{2}$ & 3.30 & 3.33 \\
\hline Dicalcium phosphate & 1.45 & 1.00 \\
\hline Limestone & 0.00 & 0.91 \\
\hline Ammonium sulfate & 0.28 & 0.28 \\
\hline Sodium bicarbonate & 0.00 & 1.12 \\
\hline Vitamin premix ${ }^{3}$ & 0.56 & 0.56 \\
\hline Trace mineralized salt ${ }^{4}$ & 0.56 & 0.56 \\
\hline Magnesium oxide & 0.33 & 0.34 \\
\hline \multicolumn{3}{|l|}{ Chemical composition } \\
\hline Ash & 10.9 & 10.2 \\
\hline $\mathrm{NDF}$ & 43.1 & 31.3 \\
\hline $\mathrm{CP}$ & 17.5 & 20.4 \\
\hline
\end{tabular}

${ }^{1}$ Diets: $20=20 \%$ concentrate; $60=60 \%$ concentrate.

${ }^{2}$ Megalac (Church and Dwight Inc., Lakewood, NJ).

${ }^{3}$ Contained $2,200 \mathrm{IU} / \mathrm{g}$ of vitamin $\mathrm{A}, 1,200 \mathrm{IU} / \mathrm{g}$ of vitamin $\mathrm{D}_{3}$, and $2.2 \mathrm{IU} / \mathrm{g}$ of vitamin $\mathrm{E}$.

${ }^{4}$ Contained 95 to $98 \% \mathrm{NaCl}$ and at least $0.24 \% \mathrm{Mn}, 0.24 \% \mathrm{Fe}, 0.05 \%$ $\mathrm{Mg}, 0.032 \% \mathrm{Cu}, 0.011 \% \mathrm{Co}, 0.007 \% \mathrm{I}$, and $0.005 \% \mathrm{Zn}$.

$60 \%$ forage compared with a diet with $40 \%$ forage. Likewise, in the same study internal fat mobilization and the concentration of energy in mobilized or accreted tissue varied with stage of lactation. Therefore, objectives of this study were to determine effects of dietary concentrate or forage level and stage of lactation on energy utilization by Alpine dairy goats.

\section{MATERIALS AND METHODS}

\section{Animals, Diets, and Measurement Times}

The protocol for this experiment was approved by the Langston University Animal Care and Use Committee (Langston, OK). Thirty-seven Alpine does were used, 24 lactating and 13 nonpregnant and nonlactating. Seven lactating does were primiparous and 17 were in the second or third lactation. Of the dry does, 4 had 1 previous lactation and 9 had 2 or 3 past lactation periods. Primiparous does were 2.0 yr of age (SEM = 0.05 ) when the experiment began, and multiparous does were $3.7 \mathrm{yr}$ of age $(\mathrm{SEM}=0.18)$. As kidding occurred, at $3 \mathrm{~d}$ after parturition does in sets of 2 were randomly assigned to either a $60 \%$ concentrate $\operatorname{diet}(\mathbf{6 0 \%} \mathbf{C})$ or a $20 \%$ concentrate diet $(\mathbf{2 0 \%} \mathbf{C}$; Table 1$)$. Does were vaccinated against clostridial organisms and treated for internal parasites (Valbazen, SmithKline Beecham Animal Health, West Chester, PA) before kidding.

During most of the experiment, does were housed in pens $(4 \times 6 \mathrm{~m})$ in a building with individual feeding by Calan gates (American Calan Inc., Northwood, NH) and continual access to water. Artificial lighting was used from the beginning of milking at $0500 \mathrm{~h}$ until after milking all animals of the Langston University dairy herd at approximately $1800 \mathrm{~h}$. The experiment began in mid May and, thus, occurred in late spring, summer, and fall. The building included windows for ventilation and fans for greater air circulation during warm periods. Patra et al. (2009) conducted an experiment in the same building and noted similar temperature and relative humidity as outside.

Twelve lactating does were fed each diet, 7 dry does received the $60 \% \mathrm{C}$ diet, and the remaining 6 dry does received the $20 \% \mathrm{C}$ diet. Intake by lactating does was ad libitum, with diets offered at $110 \%$ of consumption on the preceding few days at 0800 and $1500 \mathrm{~h}$ (70 and 30\% of the daily allocation, respectively). Dry does were fed amounts of diets to provide $\mathrm{ME}$ near a requirement for maintenance ( $\mathbf{M E}_{\mathbf{m}}$; AFRC, 1998). Assumed dietary $\mathrm{ME}$ concentrations were based on feedstuff composition of NRC (1981). Equal amounts of diets were fed to dry does at 0800 and $1500 \mathrm{~h}$.

On d 18, 80, and 169 of lactation, sets of 3 or 4 lactating or dry does were moved sequentially to metabolism crates equipped with head boxes for adaptation to conditions similar to those used later for calorimetry measurements. After $7 \mathrm{~d}$ of adaptation, total feces and urine collections and calorimetry measures were taken over a 7-d period.

\section{Nutrient Balance}

Fecal and urine collections occurred on d 25 to 31 (early), 87 to 94 (middle), and 176 to 183 (late) of lactation. Feces were collected in wire-screen baskets placed under the floor of the metabolism crates, and urine was collected through a funnel into plastic buckets containing $50 \mathrm{~mL}$ of $12 \%$ ( $\mathrm{vol} / \mathrm{vol}$ ) hydrochloric acid. Subsamples $(20 \%)$ of feces and urine were collected daily and stored at $-20^{\circ} \mathrm{C}$. Feed, feed refusal, and fecal samples were first dried in a forced-air oven at $55^{\circ} \mathrm{C}$ for $48 \mathrm{~h}$ and then ground to pass a 1-mm screen. Feed and feed refusal samples were analyzed for DM, ash, N, gross energy (GE) (AOAC, 1990), and NDF (filter bag technique; Ankom Technology Corp., Fairport, NY), and fecal samples were analyzed for DM, ash, GE, N, and NDF. Urine samples were assayed for DM (lyophilization; model CRVP-195P Dura Stop, FTS Systems, Stone Ridge, NY), and N and GE concentrations were determined with dried samples. Does were milked 
twice daily at 0500 and $1600 \mathrm{~h}$. Milk samples were collected at both times on $\mathrm{d} 1,4$, and 7 of the 3 collection periods. Samples were analyzed for fat, protein, lactose, and TS at the certified DHIA Laboratory for Goats at Langston University. Milk composition was determined with a MilkoScan 400 analyzer (Foss Electric, Hillerød, Denmark) that was calibrated monthly. Additional milk samples (approximately $50 \mathrm{~g}$ ) were collected and frozen at $-20^{\circ} \mathrm{C}$ until being lyophilized to determine DM concentration. Dry samples were used to determine GE.

\section{Calorimetry Measures}

Gas exchange measurements for both lactating and dry does were performed the last $2 \mathrm{~d}$ of the 7 - $\mathrm{d}$ period for fecal and urine collections. Does were moved into a calorimetry room with 4 metabolism crates fitted with head boxes. The indirect open-circuit calorimetry system was described previously by Tovar-Luna et al. (2007). The concentration of $\mathrm{O}_{2}$ was analyzed using a fuel cell FC-1B $\mathrm{O}_{2}$ analyzer (Sable Systems, Las Vegas, $\mathrm{NV})$. Concentrations of $\mathrm{CO}_{2}$ and $\mathrm{CH}_{4}$ were measured using infrared analyzers (FC-1B for $\mathrm{CO}_{2}$ and MA-1 for $\mathrm{CH}_{4}$; Sable Systems). Air was first analyzed for $\mathrm{CH}_{4}$ and then for $\mathrm{CO}_{2}$ and $\mathrm{O}_{2}$. Prior to the gas exchange measurements, validity and accuracy of expired $\mathrm{CO}_{2}$ and inspired $\mathrm{O}_{2}$ flows were checked with ethanol combustion with the same flow rates as used during measurements. Before each test, analyzers were calibrated with reference gas mixtures $\left(19.5\right.$ and $20.5 \% \mathrm{O}_{2}, 0.0$ and $1.5 \% \mathrm{CO}_{2}$, and 0.0 and $0.3 \% \mathrm{CH}_{4}$, with 2 concentrations of each gas). Temperature $\left(20-23^{\circ} \mathrm{C}\right)$ in the calorimetry room was maintained with a window air conditioning-heating unit (Carrier, Farmington, CT), and humidity was 50 to $55 \%$ through use of a dehumidifier (Whirlpool, Benton Harbor, MI). The natural photoperiod was mimicked by use of fluorescent lights. After measurements for nonlactating animals while being fed, there was a 4-d fasting period with gas exchange measurement during the final $2 \mathrm{~d}$.

\section{Calculations}

Intake of ME (MEI) was calculated from GE intake and energy losses in feces, urine, and $\mathrm{CH}_{4}$. Energy expenditure or heat energy (HE) was estimated based on the Brouwer (1965) equation from $\mathrm{O}_{2}$ consumption and $\mathrm{CO}_{2}$ and $\mathrm{CH}_{4}$ production on days of gas exchange measurement, as well as urinary $\mathrm{N}$ excretion. The $\mathrm{ME}_{\mathrm{m}}$ was determined from fasting or resting $\mathrm{HE}$ of nonlactating does divided by the efficiency of ME utilization for maintenance $\left(\mathbf{k}_{\mathrm{m}}\right.$, expressed in \%), which was 100 minus the slope of the regression of HE against MEI when fed and fasted. Averages of fasting $\mathrm{HE}$ and $\mathrm{ME}_{\mathrm{m}}$ in kilojoules per kilogram of $\mathrm{BW}^{0.75}$ and $\mathrm{k}_{\mathrm{m}}$ of nonlactating does were assumed for lactating does fed the same diets at corresponding times of measurement.

Recovered energy (RE) was determined as the difference between MEI and HE. Recovered energy in milk (i.e., lactation; $\mathbf{R E}_{1}$ ) was based on milk yield and concentrations of DM and GE. When $\mathrm{RE}_{1}$ was equal to or less than RE, no tissue mobilization was assumed. If $\mathrm{RE}_{1}$ was greater than $\mathrm{RE}$, the difference was milk energy arising from mobilized tissue $\left(\mathbf{R E}_{\mathrm{lt}}\right)$. Tissue energy mobilized to produce $\mathrm{RE}_{\mathrm{lt}}\left(\mathrm{ME}_{\mathrm{lt}}\right)$ and $\mathrm{HE}$ associated with use of mobilized tissue energy for milk synthesis $\left(\mathbf{H E}_{\mathrm{lt}}\right)$ were determined assuming an efficiency of $84 \%$ (AFRC, 1998). The difference between $R E_{1}$ and $R E_{l t}$ was milk energy from dietary $\mathrm{ME}\left(\mathbf{R E}_{\mathrm{ld}}\right)$. It was assumed that all mobilized tissue energy was used for lactation, with energy used for maintenance derived exclusively from dietary ME. When $\mathrm{RE}$ was greater than $\mathrm{RE}_{1}$, the difference was attributed to $\mathrm{RE}$ in tissue gain $\left(\mathbf{R E}_{\mathrm{g}}\right)$. Heat energy associated with $\mathrm{RE}_{\mathrm{g}}\left(\mathbf{H E}_{\mathbf{g}}\right)$ and $\mathrm{ME}$ used for tissue gain $\left(\mathbf{M E}_{\mathrm{g}}\right)$ were based on an assumed efficiency of dietary ME use for tissue gain of $75 \%$ (AFRC, 1998). The amount of HE associated with use of dietary ME for lactation $\left(\mathbf{H E}_{\mathrm{ld}}\right)$ was estimated as the difference between total $\mathrm{HE}$ and the sum of $\mathrm{ME}_{\mathrm{m}}, \mathrm{HE}_{\mathrm{lt}}$, and $\mathrm{HE}_{\mathrm{g}}$. The amount of dietary ME used for lactation $\left(\mathbf{M E}_{\mathrm{ld}}\right)$ was the sum of $R E_{\text {ld }}$ and $H_{\mathrm{ld}}$. The efficiency of use of $\mathrm{ME}_{\mathrm{ld}}\left(\mathbf{k}_{\mathrm{ld}}\right.$, in \%) was calculated as $\mathrm{RE}_{\mathrm{ld}}$ divided by $\mathrm{ME}_{\mathrm{ld}}$. Also, an overall efficiency of use of $\mathrm{ME}\left(\mathbf{k}_{\mathbf{l}}\right)$ was estimated as the sum of fasting $\mathrm{HE}$ and $\mathrm{RE}_{\mathrm{ld}}$ divided by MEI. This $\mathrm{k}_{1}$ and RE were the only calculations involving MEI. Because $\mathrm{HE}_{\mathrm{ld}}$ and, thus, $\mathrm{ME}_{\mathrm{ld}}$ were estimated based on HE rather than MEI, the sum of $\mathrm{ME}_{\mathrm{ld}}, \mathrm{ME}_{\mathrm{m}}$, and $\mathrm{ME}_{\mathrm{g}}$ may not be identical to MEI.

\section{Statistical Analysis}

Data of lactating and nonlactating does were analyzed separately. Some data were omitted from statistical analyses. One nonlactating animal $(60 \% \mathrm{C}$ in late lactation) had relatively low feed intake during the period of measurement of intake, digestibility, and HE. Likewise, several lactating animals had low intake during a measurement period (e.g., $70 \%$ or less than consumed at earlier times). Moreover, there was an undetected problem in one of the 4 calorimetry measurement systems in late lactation. Ultimately, the number of observations was 11 in early and mid lactation for each diet and 8 and 7 in late lactation for the $60 \% \mathrm{C}$ and $20 \% \mathrm{C}$ diets, respectively.

Data were analyzed using the MIXED procedure of SAS (SAS Institute Inc., Cary, NC). The initial model consisted of fixed effects of diet, the repeated measure 
Table 2. Body weight, intake, and digestion for nonlactating Alpine does consuming 60 or $20 \%$ concentrate diets $^{1}$ at times corresponding to early, middle, and late stages of lactation of lactating does

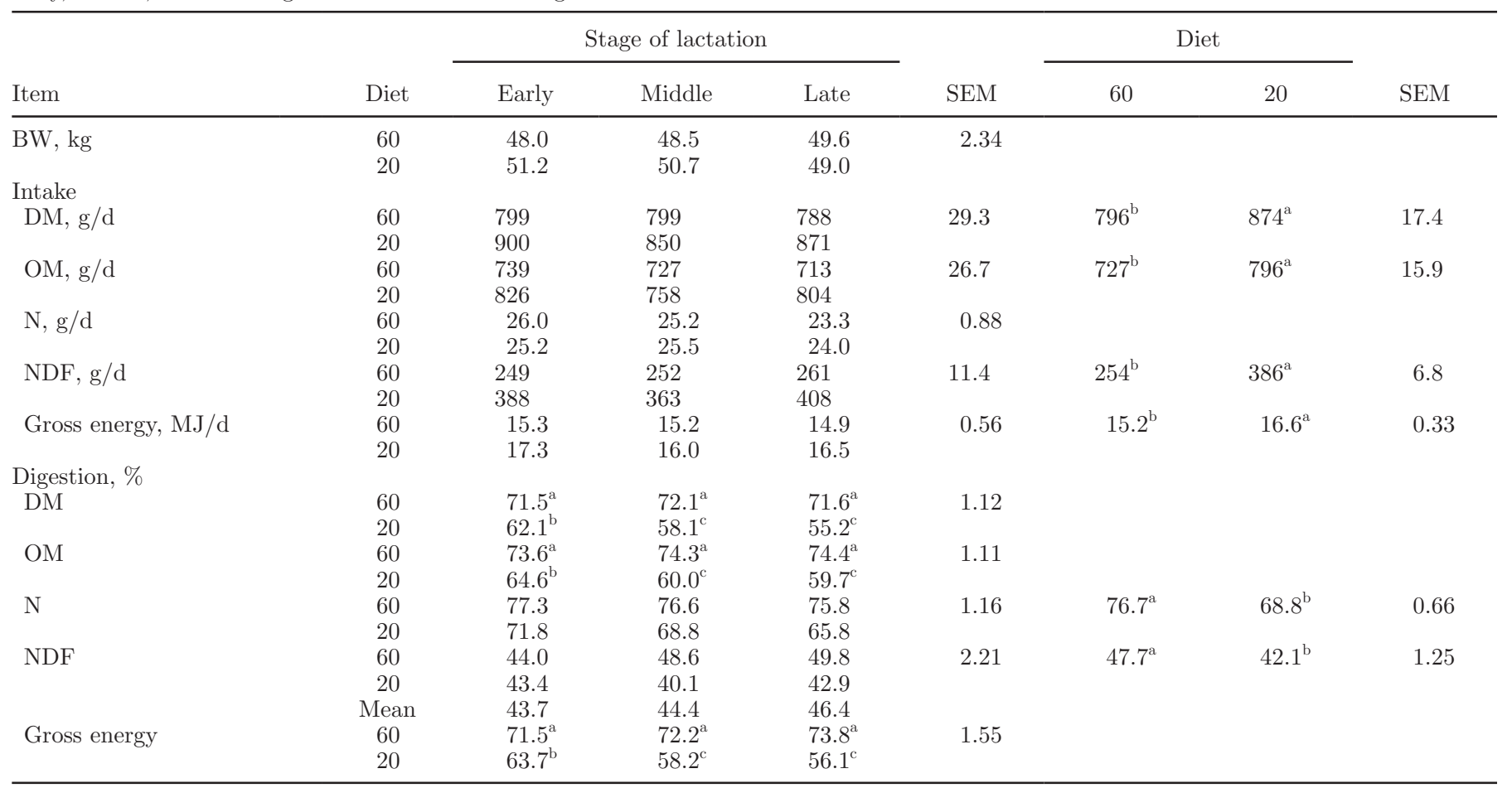

${ }^{\mathrm{a}-\mathrm{c}}$ Means within diet, stage of lactation, or diet $\times$ stage of lactation groupings with different superscripts differ $(P<0.05)$.

${ }^{1}$ Diets: $60=60 \%$ concentrate; $20=20 \%$ concentrate.

of stage of lactation, the dietary treatment $\times$ stage of lactation interaction, parity, and interactions involving parity, as well as the random effect of animal within dietary treatment. Neither effects of parity nor interactions involving parity were significant and, thus, were dropped from the model. Means were separated by least significant difference with a protected $F$-test $(P$ $<0.05$ ). Interaction means are presented in tables for all variables. Main effect means appear in tables when the interaction between dietary treatment and stage of lactation was nonsignificant and when the main effect was significant.

\section{RESULTS}

\section{Diet Composition}

Most notable differences in ingredient composition between the $20 \% \mathrm{C}$ and $60 \% \mathrm{C}$ diets were levels of alfalfa hay and ground corn (Table 1). Because alfalfa is a legume low in fiber compared with feedstuffs such as grass hay, the difference in dietary NDF concentration was only approximately 12 percentage units. Dietary $\mathrm{CP}$ concentrations were in excess of requirements (NRC, 2007), with each diet including feedstuffs relatively high in rumen undegraded intake protein (i.e., blood and fish meals). The $60 \% \mathrm{C}$ diet included sodium bicarbonate to prevent low $\mathrm{pH}$.

\section{Nonlactating Animals}

$B W$, Feed Intake, and Digestibility. Body weight was similar among stages of lactation and between diets (Table 2). Dry matter intake was $10 \%$ greater $(P$ $<0.05)$ for the $20 \% \mathrm{C}$ compared with the $60 \% \mathrm{C}$ diet. Nitrogen intake was not affected by stage of lactation or diet. Intake of NDF was $52 \%$ greater for $20 \% \mathrm{C}$ than for the $60 \% \mathrm{C}$ diet $(P<0.05)$.

Digestibilities of DM, OM, and GE were greater for the $60 \% \mathrm{C}$ than for the $20 \% \mathrm{C}$ diet $(P<0.05)$ and were greater for the $20 \% \mathrm{C}$ diet in early compared with mid and late lactation $(P<0.05$; Table 2$)$. Digestibilities of $\mathrm{N}$ were fairly similar to predictions based on relationships determined by Moore et al. (2004), although the difference between diets $(P<0.05)$ was slightly greater than expected, presumably because of the greater proportion of forage $\mathrm{N}$ in the $20 \% \mathrm{C}$ compared with the $60 \% \mathrm{C}$ diet. As expected, NDF digestibility was greater for the $60 \% \mathrm{C}$ than for the $20 \% \mathrm{C}$ diet in response to the greater proportion of legume in the $20 \% \mathrm{C}$ than in the $60 \% \mathrm{C}$ diet. 
Table 3. Energy utilization by nonlactating Alpine does consuming 60 or $20 \%$ concentrate diets $^{1}$ at times corresponding to early, middle, and late stages of lactation of lactating does

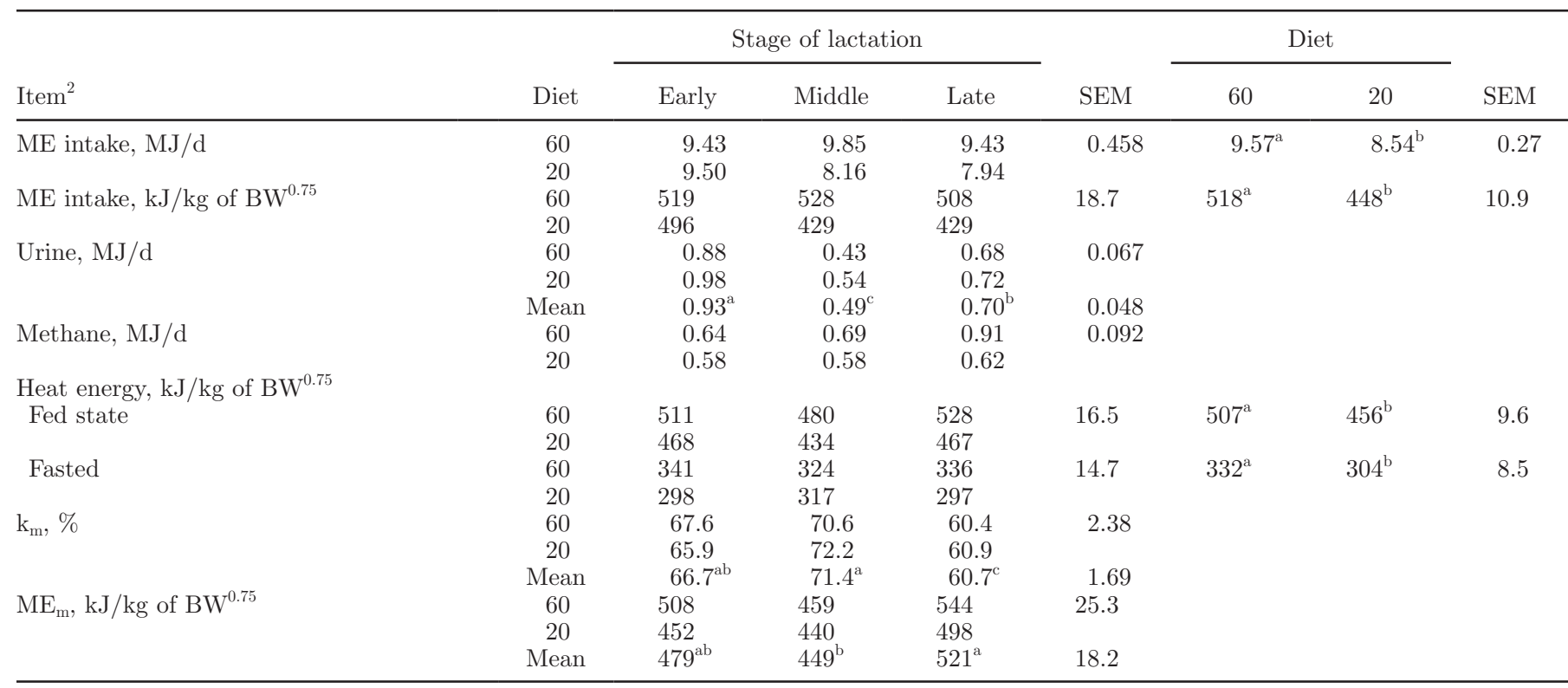

${ }^{\mathrm{a}-\mathrm{c}}$ Means within diet, stage of lactation, or diet $\times$ stage of lactation groupings with different superscripts $\operatorname{differ}(P<0.05)$.

${ }^{1}$ Diets: $60=60 \%$ concentrate; $20=20 \%$ concentrate.

${ }^{2} \mathrm{k}_{\mathrm{m}}=$ efficiency of ME utilization for maintenance; $\mathrm{ME}_{\mathrm{m}}=\mathrm{ME}$ used for maintenance.

It was planned that MEI would be similar between diets. Nonetheless, because of differences between actual and assumed dietary ME concentrations, MEI was approximately $1 \mathrm{MJ} / \mathrm{d}$ and $70 \mathrm{~kJ} / \mathrm{kg}$ of $\mathrm{BW}^{0.75}$ greater for the $60 \% \mathrm{C}$ than for the $20 \% \mathrm{C}$ diet $(P<0.05$; Table $3)$. Energy losses in urine and $\mathrm{CH}_{4}$ were similar between diets, although urinary energy ranked $(P<0.05)$ as follows: early $>$ late $>$ mid lactation.

Heat, Energy, $\boldsymbol{M E}_{\mathrm{m}}$, and $\boldsymbol{k}_{\mathrm{m}}$. Heat energy when fed was similar to MEI and greater for the $60 \% \mathrm{C}$ than for the $20 \% \mathrm{C}$ diet $(P<0.05$; Table 3$)$. Likewise, fasting $\mathrm{HE}$ was greater for the $60 \% \mathrm{C}$ than for the $20 \% \mathrm{C}$ diet $(P<0.05)$, but the magnitude of difference $(P<0.05$; $28 \mathrm{~kJ} / \mathrm{kg}$ of $\left.\mathrm{BW}^{0.75}\right)$ was slightly less than that in fed HE $\left(49 \mathrm{~kJ} / \mathrm{kg}\right.$ of $\left.\mathrm{BW}^{0.75}\right)$. The $\mathrm{k}_{\mathrm{m}}$ was similar between diets but was lowest among stages of lactation in the late period $(P<0.05)$ and tended to be greater in mid than in early lactation $(P<0.08)$. Corresponding differences in $\mathrm{ME}_{\mathrm{m}}$ were observed, although the value for the $60 \% \mathrm{C}$ diet tended $(P<0.08)$ to be greater than for the $20 \% \mathrm{C}$ diet. This tendency as well as similar $\mathrm{k}_{\mathrm{m}}$ may have been influenced by greater MEI for the $60 \% \mathrm{C}$ diet, resulting in MEI averaging $11 \mathrm{~kJ} / \mathrm{kg}$ of $\mathrm{BW}^{0.75}$ greater than $\mathrm{HE}$ for the $60 \% \mathrm{C}$ diet and $8 \mathrm{~kJ} / \mathrm{kg}$ of $\mathrm{BW}^{0.75}$ lower for the $20 \% \mathrm{C}$ diet. Hence, the $\mathrm{k}_{\mathrm{m}}$ for the $60 \% \mathrm{C}$ diet could have been slightly underestimated because of a small amount of tissue energy accretion with a lower efficiency than the true efficiency of dietary ME uti- lization for maintenance. Using regression analysis to estimate $\mathrm{ME}_{\mathrm{m}}$ of Freetly et al. (2006) by regressing RE $\left(\mathrm{kJ} / \mathrm{kg}\right.$ of $\left.\mathrm{BW}^{0.75}\right)$ against MEI $\left(\mathrm{kJ} / \mathrm{kg}\right.$ of $\left.\mathrm{BW}^{0.75}\right)$, the resultant equation from data of all lactating animals $\left[\mathrm{RE}=-319.8+(0.6849 \times \mathrm{MEI}) ; \mathrm{R}^{2}=0.90\right]$ yielded an $\mathrm{ME}_{\mathrm{m}}$ of $467 \mathrm{~kJ} / \mathrm{kg}$ of $\mathrm{BW}^{0.75}$, which was fairly similar to the mean value determined in the present experiment with nonlactating does (i.e., $483 \mathrm{~kJ} / \mathrm{kg}$ of $\mathrm{BW}^{0.75}$ ).

\section{Lactating Animals}

$B W$ and Milk Yield and Composition. Body weight was greater for $20 \% \mathrm{C}$ animals than for $60 \% \mathrm{C}$ animals $(P<0.05$; Table 4$)$. The allocation to diets was random in sets of 2 animals as kidding occurred. Hence, this difference in BW appears to have been a result of the dietary treatment assignment rather than a true dietary difference. Milk yield was greater in early and mid lactation than in late lactation and was greater for the $60 \% \mathrm{C}$ compared with the $20 \% \mathrm{C} \operatorname{diet}(P<0.05)$. As expected, milk fat concentration was greatest in late lactation $(P<0.05)$. However, the greater fat concentration for the $60 \% \mathrm{C}$ compared with the $20 \% \mathrm{C}$ diet $(P$ $<0.05)$ was not anticipated. In part, this difference suggests that dietary inclusion of sodium bicarbonate prevented low ruminal $\mathrm{pH}$ and its potential negative effect on milk fat concentration. The lower effective fiber level in the legume hay used compared with other 
Table 4. Body weight and milk yield and composition of Alpine does consuming 60 or $20 \%$ concentrate diets $^{1}$ in early, middle, and late stages of lactation

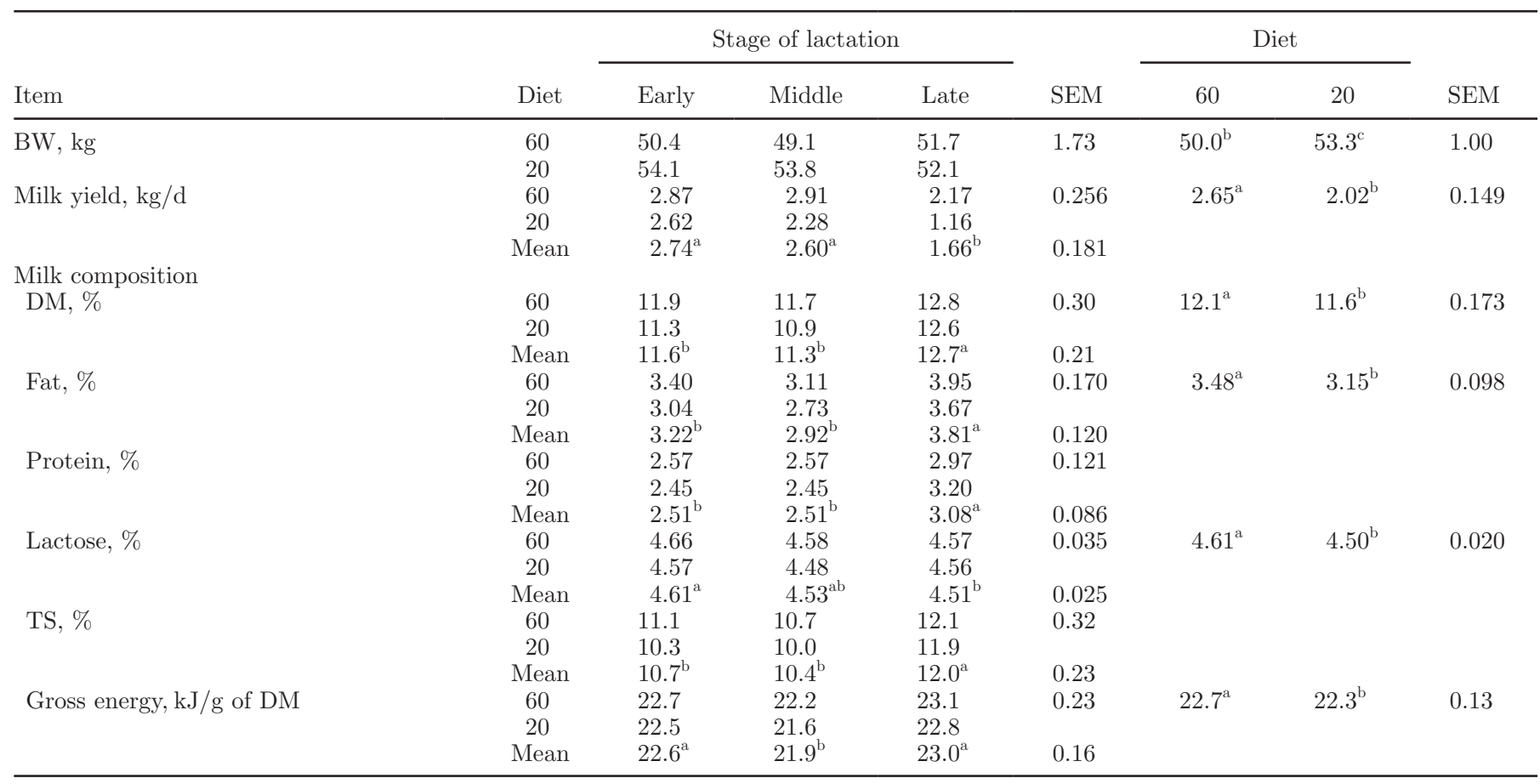

${ }^{\mathrm{a}-\mathrm{c}}$ Means within diet $\times$ stage of lactation, diet, or stage of lactation grouping with different superscripts differ $(P<0.05)$.

${ }^{1}$ Diets: $60=60 \%$ concentrate; $20=20 \%$ concentrate.

forages such as grass hay and cottonseed hulls also may have been involved in this difference. Similar to the level of fat, milk protein concentration was greatest $(P$ $<0.05)$ in late lactation.

Feed Intake and Digestibility. Ad libitum intakes of DM, OM, and GE were similar among stages of lactation and between diets (Table 5). Intake of NDF was greater for the $20 \% \mathrm{C}$ compared with the $60 \% \mathrm{C}$ diet $(P<0.05)$. Digestibilities of DM, OM, and GE were slightly lower for lactating than for nonlactating animals. Also in accordance with values for nonlactating animals, these digestibilities were greater for the $60 \% \mathrm{C}$ than for the $20 \% \mathrm{C}$ diet and for the $20 \% \mathrm{C}$ diet ranked $(P<0.05)$ as follows: early $>$ mid $>$ late lactation. The difference in $\mathrm{N}$ digestibility between diets for lactating animals was of similar magnitude to that for nonlactating animals. In accordance with greater DMI for lactating animals than for nonlactating animals (Moore et al., 2004), N digestibility was slightly less for animals when lactating. Intake of $\mathrm{ME}$ was greater for the $60 \% \mathrm{C}$ than for the $20 \% \mathrm{C}$ diet $(P<0.05$; Table $6)$. Similar to nonlactating animals, urinary energy was greatest among stages in early lactation $(P<0.05)$. Methane emission was similar among stages of lactation and between diets.
Energy Utilization. Tissue energy change, loss or accretion, tended $(P<0.07)$ to vary with stage of lactation (Table 6). All diet $\times$ stage of lactation interaction treatment means were negative, in accordance with ADG from the beginning of periods to the start of calorimetry periods (i.e., $-87,-14$, and -5 $\mathrm{g} / \mathrm{d}$ in early, mid, and late lactation, respectively; SEM $=11.2$ ). Means for tissue energy change differed from those for $\mathrm{ME}_{\mathrm{lt}}$ and $\mathrm{ME}_{\mathrm{g}}$ because when no energy was mobilized from or accreted in tissue, the corresponding variable was set at 0 .

Total HE was not affected by stage of lactation or diet (Table 6 ). In accordance with data for nonlactating animals, $\mathrm{ME}_{\mathrm{m}}$ was lowest in mid lactation $(P<0.05)$ and tended $(P<0.07)$ to be greater in late lactation than in early lactation. Heat energy associated with use of dietary ME for lactation was greater $(P<0.05)$ in mid lactation than in early and late lactation. Conversely, $R E_{l_{d}}$ and $M E_{l d}$ did not vary among stages of lactation. These findings were a function of the lower $\mathrm{k}_{\mathrm{ld}}$ for mid lactation than for late lactation $(P<0.05)$ and a tendency $(P<0.07)$ for a lower value for mid lactation than for early lactation. Differences in $\mathrm{k}_{\mathrm{ld}}$ among stages of lactation primarily resulted from relatively low $\mathrm{ME}_{\mathrm{m}}$ in mid lactation, which again was estimated 
Table 5. Intake and digestion by Alpine does consuming 60 or $20 \%$ concentrate diets $^{1}$ in early, middle, and late stages of lactation

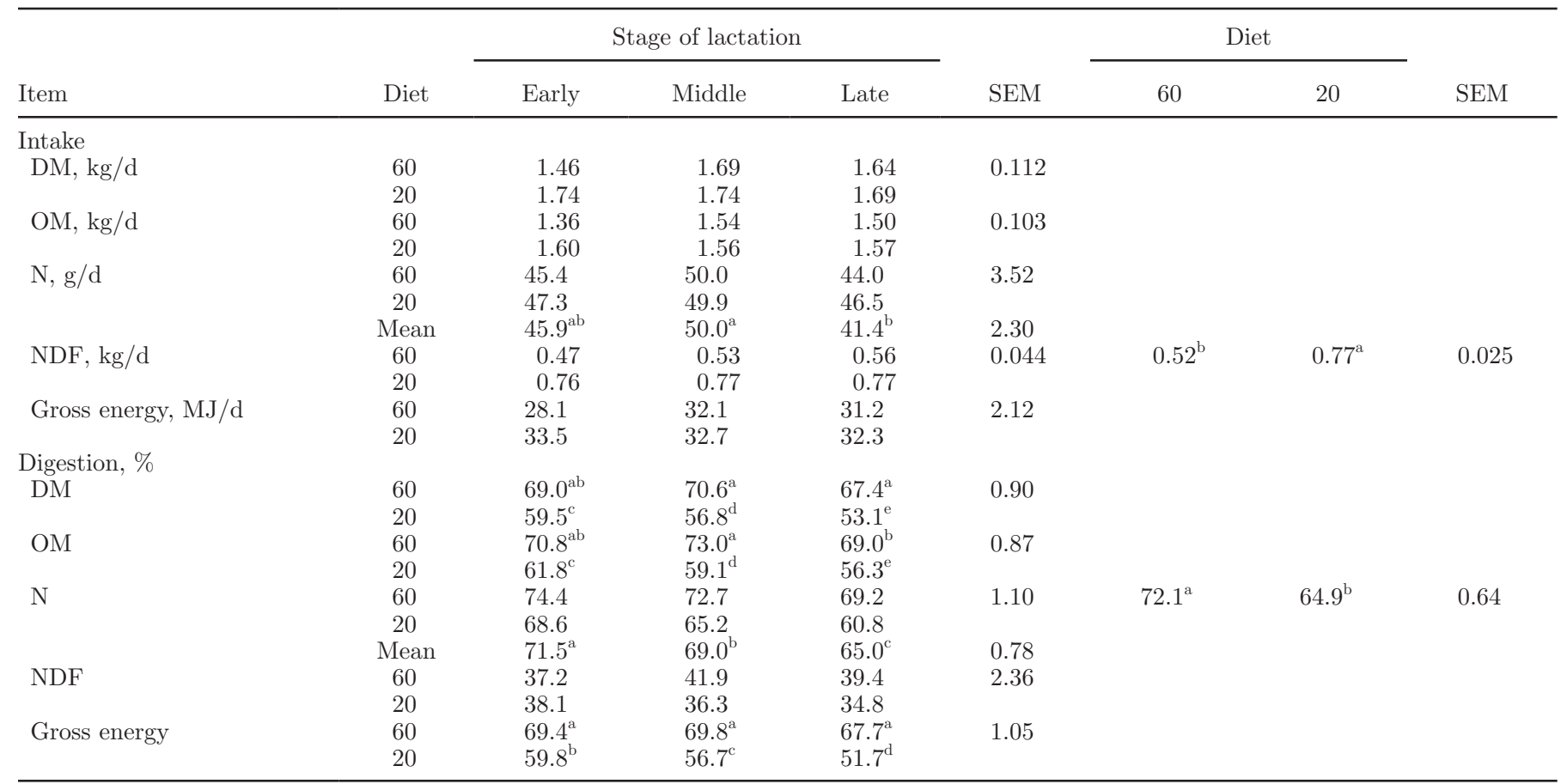

${ }^{a-e}$ Means within diet $\times$ stage of lactation, diet, or stage of lactation grouping with different superscripts differ $(P<0.05)$.

${ }^{1}$ Diets: $60=60 \%$ concentrate; $20=20 \%$ concentrate.

from data of nonlactating animals. In this regard, when the efficiency of energy use for $\mathrm{ME}_{\mathrm{m}}$ and lactation were considered together (i.e., $\mathrm{k}_{1}$ ), efficiency of energy utilization was similar among stages of lactation.

Heat energy associated with use of mobilized tissue energy for lactation was greater in early lactation than in mid $(P<0.08)$ and late $(P<0.05)$ lactation (Table $6)$. Similar results were noted for $\mathrm{RE}_{\mathrm{lt}}$ and $\mathrm{ME}_{\mathrm{lt}}$. Neither $\mathrm{HE}_{\mathrm{g}}, \mathrm{RE}_{\mathrm{g}}$, nor $\mathrm{ME}_{\mathrm{g}}$ was influenced by stage of lactation or diet. Although treatment means indicate that tissue was mobilized for milk production throughout lactation, again it is relevant to note that when no mobilization occurred, $\mathrm{HE}_{\mathrm{lt}}, \mathrm{RE}_{\mathrm{lt}}$, and $\mathrm{ME}_{\mathrm{lt}}$ were set at 0 , with the same consideration for estimation of $\mathrm{HE}_{\mathrm{g}}$, $\mathrm{RE}_{\mathrm{g}}$, and $\mathrm{ME}_{\mathrm{g}}$ when no tissue energy was accreted. In accordance, no treatment means for the latter variables differed from $0(P>0.10)$.

Total $\mathrm{RE}$ and $\mathrm{RE}_{1}$ were greater for the $60 \% \mathrm{C}$ than for the $20 \% \mathrm{C}$ diet $(P<0.05)$ because of differences $(P$ $<0.05)$ of similar magnitude in $\mathrm{RE}_{1}$ and $\mathrm{RE}_{\mathrm{ld}}$ and not involving $\mathrm{RE}_{\mathrm{lt}}$ or $\mathrm{RE}_{\mathrm{g}}$ (Table 6). Dietary $\mathrm{ME}$ used for lactation also tended to be greater $(P<0.06)$ for the $60 \% \mathrm{C}$ than for the $20 \% \mathrm{C}$ diet. The primary reason for the dietary difference in $\mathrm{RE}_{1}, \mathrm{RE}_{\mathrm{ld}}$, and $\mathrm{ME}_{\mathrm{ld}}$ was the greater $\mathrm{k}_{\mathrm{ld}}$ for the $60 \% \mathrm{C}$ diet $(P<0.05)$. The greater magnitude of difference between diets in $\mathrm{k}_{\text {ld }}$ compared with $\mathrm{k}_{1}(P<0.05)$ was a consequence of the similar $\mathrm{k}_{\mathrm{m}}$ between diets determined with nonlactating animals. With the approach of Freetly et al. (2006) for beef cows of regressing $\mathrm{RE}_{\mathrm{ld}}$ against $\mathrm{ME}_{\mathrm{ld}}$ to estimate $\mathrm{k}_{\mathrm{ld}}$, use of all lactating doe data resulted in a value of $58.1 \%\left[\mathrm{RE}_{\mathrm{ld}}\right.$ $\left.=0.8766+\left(0.5808 \times \mathrm{ME}_{\mathrm{ld}}\right) ; \mathrm{R}^{2}=0.83\right]$, which was quite similar to the average of treatment means of the present experiment.

\section{DISCUSSION}

\section{Digestibility}

Because DMI was similar among stages of lactation, greater DM, OM, and GE digestibilites for nonlactating animals fed the $20 \% \mathrm{C}$ diet in early lactation compared with in mid and late lactation would not appear related to ruminal residence time of digesta. However, it is reasonable to assume that more rapid passage of digesta from the reticulorumen in lactating animals compared with nonlactating animals, because of greater DMI by lactating animals, contributed to lower digestibilities. Differences in digestibilities between nonlactating and lactating animals were of a magnitude similar to that suggested by AFRC (1998) to account for effects of level of feed intake (i.e., 1.8\% decrease per unit increase in feeding level above $\mathrm{ME}_{\mathrm{m}}$ ). The dietary fiber level did not seem responsible for differences in digestion between stages of lactation with the $20 \% \mathrm{C}$ diet, as the dietary 
NDF concentration averaged $40.1,40.3$, and $44.1 \%$ in early, mid, and late lactation, respectively.

\section{Energy Use for Maintenance}

The $\mathrm{k}_{\mathrm{m}}$ predicted based on the formula of AFRC (1998), $[(0.35 \times$ diet metabolizability $)+0.503] \times 100$, was 73.1 and $66.9 \%$ for the $60 \% \mathrm{C}$ and $20 \% \mathrm{C}$ diets, respectively. Hence, $\mathrm{k}_{\mathrm{m}}$ in the present experiment was considerably less for the $60 \% \mathrm{C}$ diet than predicted by the AFRC (1998) equation but was similar for the $20 \% \mathrm{C}$ diet. The AFRC (1998) equation was suggested for all goats rather than specifically for dairy goats. In this regard, based on reports of Luo et al. (2004) and Sahlu et al. (2004), the

Table 6. Energy utilization by Alpine does consuming 60 or $20 \%$ concentrate diets ${ }^{1}$ in early, middle, and late stages of lactation

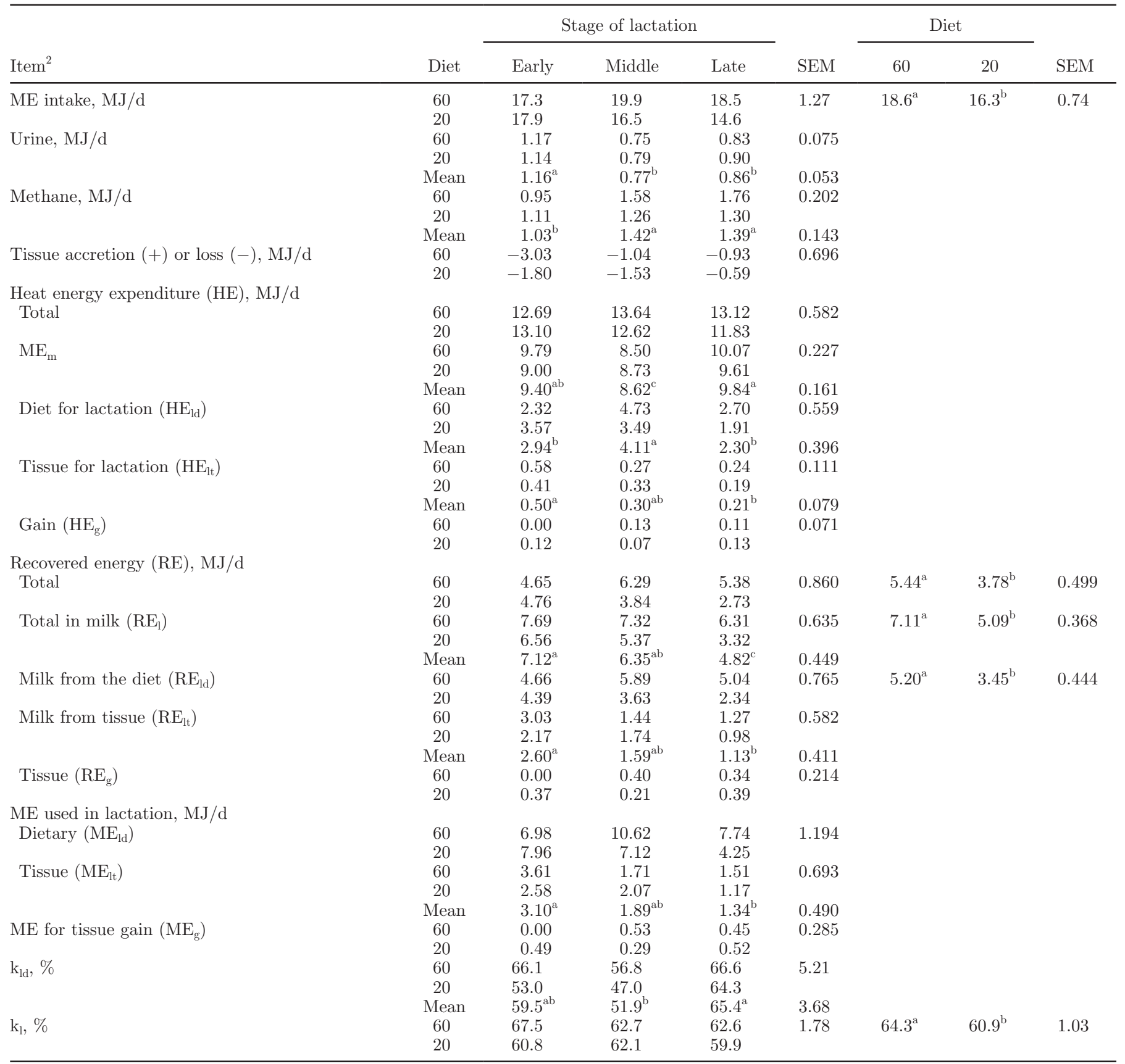

${ }^{\mathrm{a}-\mathrm{c}}$ Means within diet $\times$ stage of lactation, diet, or stage of lactation grouping with different superscripts differ $(P<0.05)$.

${ }^{1}$ Diets: $60=60 \%$ concentrate; $20=20 \%$ concentrate.

${ }^{2}$ Some abbreviations are given in parentheses to aid in viewing tables in conjunction with the text. $\mathrm{ME}_{\mathrm{m}}=\mathrm{ME}$ used for maintenance; $\mathrm{k}_{\mathrm{ld}}=$ efficiency of utilization of dietary energy for lactation; $\mathrm{k}_{1}=$ efficiency of use of dietary energy for maintenance and lactation. 
$\mathrm{ME}_{\mathrm{m}}$ requirement of dairy goats is greater than that of meat and indigenous or local goats.

The lack of difference in $\mathrm{k}_{\mathrm{m}}$ between the $60 \% \mathrm{C}$ and $20 \% \mathrm{C}$ diets in and of itself is not in accordance with the approach of Nsahlai et al. (2004) in use of the aforementioned AFRC (1998) equation. However, as noted earlier, $\mathrm{k}_{\mathrm{m}}$ for the $60 \% \mathrm{C}$ diet might have been slightly underestimated because of tissue accretion, and fasting HE could have been increased for the same reason as well. Furthermore, with the method of Nsahlai et al. (2004) in determining the ME requirement for lactation per unit of milk energy regardless of diet, inclusion of an effect of diet quality on $\mathrm{k}_{\mathrm{m}}$ seems warranted. Also, there may be compensating factors to consider. For example, $\mathrm{k}_{\mathrm{m}}$ was similar between diets and $\mathrm{k}_{\mathrm{ld}}$ was greater for the $60 \% \mathrm{C}$ than for the $20 \% \mathrm{C}$ diet in the present experiment and, conversely, Nsahlai et al. (2004) varied $\mathrm{k}_{\mathrm{m}}$ with diet metabolizability and estimated a single $\mathrm{k}_{\mathrm{ld}}$ for all diets.

The magnitude of difference between diets in fed HE of nonlactating animals is in agreement with that in fasted $\mathrm{HE}$ and similar $\mathrm{k}_{\mathrm{m}}$. Thus, factors such as potential dietary differences in the profile of nutrients absorbed were of little or no consequence. Metabolic machinery or support tissues (e.g., gastrointestinal tract and liver) to be maintained with the $60 \% \mathrm{C}$ diet presumably were greater than for the $20 \% \mathrm{C}$ diet as a consequence of greater MEI for the $60 \% \mathrm{C}$ diet (Johnson et al., 1990). Energy metabolized to satisfy this extra demand for the $60 \% \mathrm{C}$ diet incurred the same inefficiency or loss of heat above and relative to fasting $\mathrm{HE}$ as did the lesser amount of metabolic machinery being maintained with the $20 \% \mathrm{C}$ diet because of lower MEI. However, this is not necessarily directly applicable to lactating animals with higher MEI and all coordinated physiological processes involved in milk secretion.

The $\mathrm{ME}_{\mathrm{m}}$ for mature dairy goats $(501 \mathrm{~kJ} / \mathrm{kg}$ of $\mathrm{BW}^{0.75}$ ) assumed by Nsahlai et al. (2004) to estimate the requirement for milk production, recommended by Sahlu et al. (2004) and NRC (2007), was intermediate to that determined in this experiment with nonlactating animals in early and late lactation periods. The value for mid lactation was, however, considerably lower. It cannot be conclusively discerned why $\mathrm{k}_{\mathrm{m}}$ was lower and $\mathrm{ME}_{\mathrm{m}}$ was greater when determined in nonlactating animals in late lactation compared with mid lactation, with intermediate values during early lactation. Environmental conditions were conceivably involved given that the warmest period was in mid lactation. However, findings of Patra et al. (2009) with Boer and Spanish yearling doelings housed in the same facility do not support marked effects on $\mathrm{ME}_{\mathrm{m}}$ of seasonal differences in temperature and humidity. Nonetheless, with this experimental design, values for nonlactating animals were applied to lactating animals assuming similar differences among the 3 measurement times corresponding to early, mid, and late stages of lactation of lactating animals. Such an approach has limitations in that potential interactions between physiological conditions of nonlactating and lactating animals and factors such as environmental conditions and fluctuations in dietary characteristics are not considered.

\section{Energy Use for Lactation}

The lower $\mathrm{k}_{\mathrm{ld}}$ in mid lactation than in early and late stages of lactation was a function of lower $\mathrm{ME}_{\mathrm{m}}$ and greater $\mathrm{k}_{\mathrm{m}}$ estimated with nonlactating animals. Similar $\mathrm{k}_{1}$ among stages of lactation for lactating animals indicates that the overall efficiency of energy metabolism of dietary ME for maintenance and lactation did not differ among stages of lactation. Because maintenance energy requirements vary with physiological conditions as influenced by level of MEI and perhaps the origin of energy used for milk production (i.e., dietary and mobilized tissue) as well as use of energy for tissue energy accretion, given the method of estimating $\mathrm{ME}_{\mathrm{m}}$ in this experiment, $\mathrm{k}_{1}$ may be preferable to evaluate efficiency of metabolism of dietary ME or, alternatively, assessment should consider both $\mathrm{k}_{\mathrm{ld}}$ and $\mathrm{ME}_{\mathrm{m}}$. Such an approach, as used by many systems for dairy cattle (e.g., NRC, 2001), has the attribute of avoiding the issue of whether level of intake and physiological state effects on HE should be categorized as maintenance or production functions (Williams and Jenkins, 2003).

On the basis of $\mathrm{k}_{\mathrm{ld}}$ only, findings of the present experiment disagree with little or no effect of stage of lactation on the energy requirement for milk energy yield determined by Nsahlai et al. (2004). But, in regards to $\mathrm{k}_{1}$, results of this experiment are similar to findings of Nsahlai et al. (2004). In addition, with studies such as Nsahlai et al. (2004) relying on databases of treatment mean observations constructed from the literature, sometimes with less than desired clarity in the description of procedures and with experimental periods not always restricted to specific stages of lactation, evaluation of effects of factors like stage of lactation can be challenging.

The AFRC (1998) equation to predict $\mathrm{k}_{\mathrm{ld}}$, [(0.35 $\times$ diet metabolizability) +0.420$] \times 100$, yielded estimates of 64.8 and $60.6 \%$ for the $60 \% \mathrm{C}$ and $20 \% \mathrm{C}$ diets, respectively. In contrast to differences in $\mathrm{k}_{\mathrm{m}}$ between observations of the present study and AFRC (1998) predictions, for $\mathrm{k}_{\mathrm{ld}}$ values were similar with the $60 \% \mathrm{C}$ diet but greater for the AFRC (1998) prediction with the $20 \% \mathrm{C}$ diet.

Greater MEI for the $60 \% \mathrm{C}$ diet coupled with the tendency for greater $\mathrm{ME}_{\mathrm{m}}$ based on nonlactating animal 
data compared with the $20 \% \mathrm{C}$ diet may have contributed to greater $\mathrm{k}_{\mathrm{ld}}$ and $\mathrm{k}_{1}$ for the $60 \% \mathrm{C}$ than for the $20 \% \mathrm{C}$ diet. That is, with a relatively high $\mathrm{ME}_{\mathrm{m}}$ the proportion of MEI contributing to milk energy yield was correspondingly low. These results suggest that the magnitude of the effect of the difference between diets in MEI involved a threshold effect of energy availability on the cost of maintenance of metabolic machinery or support tissues involved in milk secretion. In other words, energy required for maintenance of metabolic machinery necessary for milk secretion decreased with increasing energy availability relevant to the $60 \% \mathrm{C}$ versus the $20 \% \mathrm{C}$ diet or reached a certain point above which no increase or relatively small change occurred. In addition, although the difference between diets in $\mathrm{k}_{\mathrm{ld}}$ was greater than that in $\mathrm{k}_{\mathrm{l}}$, because $\mathrm{k}_{\mathrm{m}}$ was determined with nonlactating animals at a level of intake near maintenance and $k_{l d}$ was estimated with lactating animals, it is possible that the diet effect on $k_{l d}$ was at least partially attributable to effects on energy use per unit of energy absorption by metabolically active tissues such as the gastrointestinal tract, with less effect of diets moderate to high in concentrate feedstuffs compared with ones higher in level of forage (Goetsch, 1998). But, it is also possible that differences between the $60 \% \mathrm{C}$ and $20 \% \mathrm{C}$ diets in the profile of absorbed nutrients affected $\mathrm{k}_{\mathrm{ld}}$ (NRC, 2001).

Treatment means for $\mathrm{HE}_{\mathrm{g}}, \mathrm{RE}_{\mathrm{g}}$, and $\mathrm{ME}_{\mathrm{g}}$ were low and not different from 0 . Treatment means for $\mathrm{HE}_{1 \mathrm{t}}$, $\mathrm{RE}_{\mathrm{lt}}$, and $\mathrm{ME}_{\mathrm{lt}}$ were slightly greater than those for tissue energy accretion, in agreement with ADG means that were negative for each stage of lactation. Hence, planes of nutrition throughout the lactation period did not facilitate appreciable replenishment of body energy stores, in contrast to findings of Ngwa et al. (2009), particularly in late lactation. Therefore, under these conditions a relatively high plane of nutrition after measurements in the late stage of lactation and during the subsequent dry period would be needed to attain physiological conditions conducive to optimal performance during rebreeding, gestation, and the next lactation.

\section{Prediction of Lactation Performance}

Even though limitations of methods used by Nsahlai et al. (2004) to derive energy requirements of lactating dairy goats recommended by Sahlu et al. (2004) and NRC (2007) have been addressed earlier, predictions based on those expressions of results in the present experiment were reasonably accurate given the nature of measurements taken. One of the most important estimates required for accurate prediction of milk yield at a certain level of DMI or of DMI required to achieve a specific milk yield is $\mathrm{BW}$ change or ADG. The degree to which ADG truly reflects tissue energy mobilization for use in milk secretion or energy accretion is affected by constancy of digesta mass in the digestive tract. The potential magnitude of effect of ADG on such predictions can be assessed by comparing actual milk yield with that predicted at 0 ADG. With use of the Web-based goat nutrient requirement calculation system of Langston University (www2.luresext.edu), which applies NRC (2007) recommendations, predicted milk yield with 0 ADG was $1.67,2.38,1.95,1.53,1.62$, and $1.45 \mathrm{~kg} / \mathrm{d}$ for the $60 \% \mathrm{C}$ diet in early, mid, and late lactation and for the $20 \% \mathrm{C}$ diet in early, mid, and late lactation, respectively. Observed values were considerably greater. Estimates of ADG were $-99,-21$, $-7,-76,-6$, and $-2 \mathrm{~g} / \mathrm{d}$ for the $60 \% \mathrm{C}$ diet in early, mid, and late lactation and for the $20 \% \mathrm{C}$ diet in early, mid, and late lactation, respectively $(\mathrm{SEM}=15.8)$. When the ADG means were considered, predicted milk yield was $3.17,2.70,2.03,2.67,1.72$, and $1.38 \mathrm{~kg} / \mathrm{d}$ for the $60 \% \mathrm{C}$ diet in early, mid, and late lactation and for the $20 \% \mathrm{C}$ diet in early, mid, and late lactation, respectively. These values were similar to observations, except perhaps for the $20 \% \mathrm{C}$ diet in mid lactation (difference of $0.56 \mathrm{~kg} / \mathrm{d}$ ); differences for other diet $\times$ stage of lactation interaction means ranged from -0.30 to $0.21 \mathrm{~kg} / \mathrm{d}$. Similarly, based on main effect means for dietary treatments, predicted milk yield was 2.65 and $1.90 \mathrm{~kg} / \mathrm{d}$ for the $60 \% \mathrm{C}$ and $20 \% \mathrm{C}$ diets, respectively, with the former value the same as observed and the latter value just $0.22 \mathrm{~kg} / \mathrm{d}$ less. Hence, it can be concluded that NRC (2007) energy requirement recommendations resulted in reasonably accurate predictions of findings of this experiment.

\section{CONCLUSIONS}

The $\mathrm{k}_{\mathrm{m}}$ determined with nonlactating animals differed among periods of time when lactating animals were in early, mid, and late lactation. This may have contributed to differences among stages of lactation in $\mathrm{k}_{\mathrm{ld}}$ of lactating animals. However, $\mathrm{k}_{\mathrm{l}}$ was not affected by stage of lactation. The $\mathrm{k}_{\mathrm{m}}$ for the $60 \% \mathrm{C}$ and $20 \% \mathrm{C}$ diets determined in nonlactating animals was similar, although both $\mathrm{k}_{\mathrm{ld}}$ and $\mathrm{k}_{1}$ were greater in lactating animals for the $60 \% \mathrm{C}$ than for the $20 \% \mathrm{C}$ diet. These findings demonstrate limitations of approaches to study efficiency of energy use and requirements of lactating dairy goats with maintenance needs estimated from corresponding nonlactating animals. Predictions of milk yield from energy requirement recommendations of NRC (2007) were reasonably accurate.

\section{ACKNOWLEDGMENTS}

This project was supported by USDA Project Number 99-38814-9500. 


\section{REFERENCES}

AFRC. 1993. Energy and protein requirements of ruminants. Pages 5-55 in An Advisory Manual Prepared by the AFRC Technical Committee on Responses to Nutrients. CAB International, Wallingford, UK.

AFRC. 1998. The Nutrition of Goats. CAB International, New York, NY.

AOAC. 1990. Official Methods of Analysis. 15th ed. Association of Official Analytical Chemists, Arlington, VA.

Brouwer, E. 1965. Report of sub-committee on constants and factors. Pages 441-443 in Energy Metabolism: Proc. 3rd Symp. K. L. Blaxter, ed. EAAP Publ. No. 11. Academic Press, London, UK.

Freetly, H. C., J. A. Nienaber, and T. Brown-Brandl. 2006. Partitioning of energy during lactation of primiparous beef cows. J. Anim. Sci. 84:2157-2162.

Goetsch, A. L. 1998. Splanchnic tissue energy use in ruminants that consume forage ad libitum. J. Anim. Sci. 76:2737-2746.

Johnson, D. E., K. A. Johnson, and R. L. Baldwin. 1990. Changes in liver and gastrointestinal tract energy demands in response to physiological workload in ruminants. J. Nutr. 120:649-655.

Luo, J., A. L. Goetsch, T. Sahlu, I. V. Nsahlai, Z. B. Johnson, J. E. Moore, M. L. Galyean, F. N. Owens, and C. L. Ferrell. 2004. Prediction of metabolizable energy requirements for maintenance and gain of preweaning, growing, and mature goats. Small Rumin. Res. 53:309-328.

Moore, J. E., A. L. Goetsch, J. Luo, F. N. Owens, M. L. Galyean, Z. B. Johnson, T. Sahlu, and C. L. Ferrell. 2004. Prediction of fecal crude protein excretion of goats. Small Rumin. Res. 53:275-292.

Ngwa, A. T., L. J. Dawson, R. Puchala, G. D. Detweiler, R. C. Merkel, Z. Wang, K. Tesfai, T. Sahlu, C. L. Ferrell, and A. L. Goetsch. 2009. Effects of stage of lactation and dietary concentrate level on body composition of Alpine dairy goats. J. Dairy Sci. 92:33743385 .

NRC. 1981. Nutrient Requirements of Goats: Angora, Dairy and Meat Goats in Temperate and Tropical Countries. National Academy Press, Washington, DC.

NRC. 2001. Nutrient Requirements of Dairy Cattle. 7th rev. ed. National Academy Press, Washington, DC.

NRC. 2007. Nutrient Requirements of Small Ruminants. Sheep, Goats, Cervids, and New World Camelids. National Academy Press, Washington, DC.

Nsahlai, I. V., A. L. Goetsch, J. Luo, J. E. Moore, Z. B. Johnson, T. Sahlu, C. L. Ferrell, M. L. Galyean, and F. N. Owens. 2004. Energy requirements for lactation of goats. Small Rumin. Res. $53: 253-274$

Patra, A. K., R. Puchala, G. Animut, T. A. Gipson, T. Sahlu, and A. L. Goetsch. 2009. Effects of acclimatization on energy expenditure by meat goats. Small Rumin. Res. 81:42-54.

Sahlu, T., A. L. Goetsch, J. Luo, I. V. Nsahlai, J. E. Moore, M. L. Galyean, F. N. Owens, C. L. Ferrell, and Z. B. Johnson. 2004 Energy and protein requirements of goats: Developed equations, other considerations and future research to improve them. Small Rumin. Res. 53:191-220.

Tovar-Luna, I., A. L. Goetsch, R. Puchala, T. Sahlu, G. E. Carstens, H. C. Freetly, and Z. B. Johnson. 2007. Effects of moderate feed restriction on energy expenditure by 2 -year-old crossbred Boer goats. Small Rumin. Res. 72:25-32.

Williams, C. B., and T. G. Jenkins. 2003. A dynamic model of metabolizable energy utilization in growing and mature cattle. I. Metabolizable energy utilization for maintenance and support metabolism. J. Anim. Sci. 81:1371-1381. 